NBER WORKING PAPER SERIES

\title{
THE EQUIVALENCE OF THE SOCIAL SECURITY'S TRUST FUND PORTFOLIO ALLOCATION AND CAPITAL INCOME TAX POLICY
}

\author{
Kent Smetters \\ Working Paper 8259 \\ http://www.nber.org/papers/w8259 \\ NATIONAL BUREAU OF ECONOMIC RESEARCH \\ 1050 Massachusetts Avenue \\ Cambridge, MA 02138 \\ April 2001
}

I benefitted from helpful comments and conversations with Andy Abel, Douglas Bernheim, Timothy Besley, Peter Diamond, Jon Gruber, Peter Hammond, Olivia Mitchell, Antonio Rangel, Agnar Sandmo, and participants of seminars held at MIT and Stanford. The views expressed herein are those of the author and not necessarily those of the National Bureau of Economic Research.

(C) 2001 by Kent Smetters. All rights reserved. Short sections of text, not to exceed two paragraphs, may be quoted without explicit permission provided that full credit, including $\odot$ notice, is given to the source. 
The Equivalence of the Social Security's Trust Fund Portfolio Allocation

and Capital Income Tax Policy

Kent Smetters

NBER Working Paper No. 8259

April 2001

JEL No. H3, E6, G0, H2

\begin{abstract}
$\underline{\text { ABSTRACT }}$
This paper proves that the stock-bond portfolio choice of the Social Security trust fund is equivalent in general equilibrium to the tax treatment of capital income by the non-social security part of government. A larger [smaller] share of social security's portfolio invested in stocks is equivalent to a larger [smaller] symmetric linear tax on risky capital income returns received on assets held by private agents. This general-equilibrium equivalency holds despite the fact that the stock-bond portfolio choice is not neutral in the presence of several market frictions. These frictions include incomplete markets between generations as well as the presence of endogenously binding borrowing constraints within generations. To the extent that trust fund investment in equities is used to improve market efficiency in the context of these frictions, the equivalent capital income tax rate can be interpreted as a Lindahl tax. This tax gives a decentralized way of achieving the same command-economy outcome that would occur if the government directly controlled part of the capital stock. General-equilibrium simulation results, using a new overlapping-generations model with aggregate uncertainty, suggest that investing the entire US Social Security trust fund in equities is equivalent to increasing the capital income tax rate by about 4 percentage points.
\end{abstract}

Kent Smetters

The Kaiser Visiting Professor

Stanford University (visiting 9/1/00 - 6/31/01)

Department of Economics

Stanford, CA 94305-6072

\&

Assistant Professor

The Wharton School

University of Pennsylvania

3641 Locust Walk, CPC 302

Philadelphia, PA 19104-6218

\& NBER

Tel: 215-898-9811

Fax: 215-898-0310

Email: smetters@wharton.upenn.edu 


\section{Introduction}

The classic equivalency result between the level of Social Security wealth and the level of government debt, as emphasized in the seminal works by Feldstein (1974), Barro (1974), and Miller and Upton (1974), revolutionized how economists view public spending and the government's budget constraint. ${ }^{1}$ A nation's debt level is no longer viewed by economists in isolation of the rest of the government's liabilities. The value of the US Social Security system's liabilities have been estimated to be several times larger than the size of explicit government debt. ${ }^{2}$ The equivalency between a nation's official debt and its other fiscal liabilities is the motivation behind the emerging generational accounting literature, which unifies all government liabilities within a consistent intertemporal budget constraint. ${ }^{3}$

This paper proves that an equivalency also exists between the nation's tax treatment of capital income and how assets in its Social Security' trust fund are allocated between risky capital and government bonds. Since Social Security benefits are defined by law, Social Security's capital income risk would be borne by future generations in the form of risky payroll tax rates. This paper shows that Social Security's portfolio choice can be replicated with a simple symmetric linear tax on risky capital returns by the non-Social Security part of government. In particular, a single tax instrument on capital returns can be chosen to generate the same total (public plus private) demand for capital, the same total demand for bonds, and the same tax rate on wages in all states of the world under the two policies. The two policies are, therefore, equivalent in general-equilibrium, resulting in the same consumption by all agents in each state of the world.

${ }^{1}$ The Ricardian equivalence debate, which emerged from these papers, focused on whether debt was also neutral. Although this debate is still active, the equivalency between debt and social security is now well accepted.

${ }^{2}$ See, for example, Feldstein and Samwick (1997) and Geanakoplos, Mitchell and Zeldes (1998).

${ }^{3}$ See Auerbach, Gokhale, and Kotlikoff (1994). 
The equivalency result proven herein, however, is a little more subtle than the equivalency between Social Security wealth and government debt. Debt and Social Security wealth are equivalent because they generate the same private budget constraints. As a result, the private demand for capital is the same under both policies. This budget constraint equivalence led Auerbach, Gokhale, and Kotlikoff(1994) and to refer to debt and Social Security wealth as "arbitrary labels."

In contrast, the equivalency result derived herein requires distorting the after-tax rate of return to capital saving received by private agents, thereby changing their demand for capital. ${ }^{4}$ For example, a larger linear tax rate on capital income entices private agents to increase their capital demand in order to absorb, at prevailing prices, the stock equity that Social Security could have held. The same new tax rate simultaneously causes private agents to release the same value of bonds to Social Security at current market prices. The same new tax rate also causes wage tax rates, which must be stochastic in the presence of risk, to be the same under both policies in each state of the world.

This general-equilibrium equivalency holds despite the fact that Social Security's stock-bond choice is not neutral in the presence of market frictions. These frictions include incomplete markets between generations as well as the presence of endogenously binding borrowing constraints within generations. Previous papers have demonstrated that investing the Social Security trust fund in equities can improve risk sharing in the presence of incomplete markets between generations (e.g., Bohn 1999; Social Security Advisory Council, 1997; Diamond, 1997) and within generations (Diamond and Geanakoplos, 1999; Abel, 2000). The model analyzed in Sections II - IV of this paper

\footnotetext{
${ }^{4}$ Like debt and social security wealth, the equivalency result herein can also be interpreted as maintaining the full Arrow-Debreu set of state-contingent consumption, provided that we also interpret the tax on capital income as a mandatory, but spanned, Arrow security. Indeed, all equivalency results must be Arrow-Debreu equivalent by definition.
} 
incorporates incomplete inter-generational markets. The model is modified in Section V to include incomplete markets within generations as well. The model herein is the first that I am aware of to include both.

To the extent that trust fund investment in equities is used to improve market efficiency in the context of these market frictions, the equivalent capital income tax rate can be interpreted as a Lindahl tax. This tax gives a decentralized way of achieving the same command-economy outcome that would occur if the government directly controlled part of the capital stock. The decentralized solution is particularly relevant in light of President Clinton's proposal to invest part of the Social Security trust fund in equities. His proposal re-ignited a controversy about the government's role in capital markets. The debate is not new: the idea of the government holding private equities was hotly debated among policymakers even before the passage of the 1935 US Social Security Act (Shoven and Schieber, 1999). The decentralized approach taken herein shows how to accomplish the same objective without direct government control.

Simulation results reported below suggest that investing the entire US Social Security trust fund in equities is equivalent to increasing the capital income tax rate by about 4 percentage points. These results are derived using an overlapping-generations model with aggregate uncertainty and multiple sources of shocks. The simulation model is fully general equilibrium and incorporates many features in the household sector, production sector and government sector that have been taken as exogenous in previous models.

The current paper is related to the existing literature on the taxation of risky capital income. That literature, started by Domar and Musgrave (1944), was derived most rigorously in the modern treatments by, for example, Mossin (1968), Stiglitz (1969), Sandmo (1969, 1985), Gordon (1985), and Bradford (1995). That literature demonstrated that the government already shares in investment 
risk if (i) the government taxes only the risky return around the risk-free rate and (ii) the tax is symmetric by taxing the difference between the risky and risk-free return - positive or negative. Assumption (i) is usually justified on tax law provisions, or on the low historic risk-free rate relative to the average return to equities. For example, at historical values, the 30 -year average return to equities is approximately ten times larger than the risk-free rate. So ignoring a tax on the risk-free rate may not be material even outside of tax law. Assumption (ii) is often justified on the basis of loss offset rules imbedded in the tax law. Gordon (1985) shows that these conditions hold approximately for the United States.

The previous literature on the taxation of risky capital income, though, focused on neutrality. In particular, the previous literature argued that placing a tax on capital income had no impact on consumption. Two types of models were used to show this result. The first type of model was Ricardian in which agents are connected to their future selves and are the residual claimants of all government risk. Gordon (1985), in particular, considered a single-agent two-period model. His paper was first in this literature to formally include the government's budget constraint and to explain its relevance. He proved that a tax on risk did not have any impact on the private demand for capital or bonds, or on consumption.

The second type of model in the literature is more related to classic Modigliani-Miller neutrality theorem of corporate finance. The papers in this literature abstracted from the government's budget constraint and instead focused on the saving levels and portfolio choice of private agents in the presence of capital income taxes. Mossin (1968) and Stiglitz (1969) considered capital income taxes in one-period models. The papers by Sandmo $(1969,1985)$ modernized the discussion to the context of a two-period inter-temporal choice model with multiple assets. Bradford (1995) considered the taxation of risky capital income returns in the context of fundamental tax 
reform. In these papers, agents respond to capital income taxes by re-balancing their stock-bond portfolio, thereby allowing them to achieve the same levels of consumption at given price levels. The re-balancing occurred because, unlike the pure Ricardian framework, agents were not assumed to be the full residual claimants of the government's risk.

In contrast, this paper focuses on fiscal policy equivalency. The distinction between the concepts of neutrality and equivalency is important because investing the Social Security trust fund in equities is not neutral with incomplete markets between and within generations. This paper shows that, despite both of these market frictions, the Social Security's trust fund investment policy can be replicated with a simple linear capital income tax with tax provisions (i) and (ii). Like some of the previous literature, the government's inter-temporal budget constraint is enforced. However, unlike the previous literature, the model herein allows for generations to overlap and for risks to be shared across generations, as well as for some agents to be endogenously borrowing constrained. NonRicardian sharing of risks between generations leads to portfolio re-balancing (see Lemma 1 below), as in some of the previous literature. But neutrality does not obtain due to market incompleteness and ensuing general-equilibrium changes in prices.

This paper does not consider some other important related issues. The paper does not consider political-economy issues in overlapping-generations economies (as in Rangel, 2000). Nor does this paper re-derive the conditions under which trust fund investment in equities or, equivalently, capital income taxes, would potentially increase efficiency (as in Diamond and Geanakoplos, 1999, and Smetters, 2000). Neither of these issues are necessary for demonstrating the equivalency of policies. This paper also does not focus on actual tax law provisions in different countries. Even if the tax law provisions (i) and (ii) noted above do not approximately hold for any particular country, they could always be adopted along with the correct tax rate that replicates the 
portfolio held by its Social Security system.

Section II gives an overview of the overlapping-generations model used herein. Section III derives a closed-form solution for the value of the capital income tax rate that is equivalent to the investment portfolio of the Social Security trust fund. Section IV reports simulation evidence. Section $\mathrm{V}$ extends the analysis to include agents with no saving and calculates new equivalent tax rates. Section VI concludes. 


\section{Model}

$\underline{\text { Households }}$

Without any loss in generality, suppose that agents live for two periods. Generation- $t$ consumers decide how much to save in bonds, $s^{B}$, and unleveraged capital, $s^{K}$, to maximize their expected lifetime utility over first-period consumption, $c_{1}$, and second-period consumption, $c_{2}$,

$$
\max _{s_{t}^{B}, s_{t}^{K}} E_{t} U\left(c_{1, t}, c_{2, t+1}\right)=u\left(c_{1, t}\right)+\beta E_{t} u\left(c_{2, t+1}\right)
$$

subject to the following budget constraints,

$$
\begin{gathered}
c_{1, t}+s_{t}^{K}+s_{t}^{B}=w_{t}\left(1-\tau_{t}^{S S}-\tau_{t}^{W}\right) \\
c_{2, t+1}=s_{t}^{K} \cdot\left[1+e_{t+1}-\left(e_{t+1}-r_{t+1}\right) \tau_{t+1}^{K}\right]+s_{t}^{B} \cdot\left(1+r_{t+1}\right)+b_{t+1}
\end{gathered}
$$

where the $\tau$ terms are taxes described below, $w$ is the wage rate known at time $t, e$ is the risky realized return to private capital, $r$ is the risk-free return to government debt and $b$ is the Social Security benefit. The function, $u(c)$, satisfies the usual properties: $\partial u(c) / \partial c>0, \partial^{2} u(c) / \partial c^{2}<0$, and $\lim _{c \rightarrow 0} \partial u(c) / \partial c=\infty$.

In equation (2), the sum of first-period consumption and saving in risky capital and bonds equal after-tax wages received in the first period. Workers face two taxes in their first period: a Social Security payroll tax, $\tau^{S S}$, and a wage tax, $\tau^{W}$, used to finance other government spending.

In equation (3), second-period consumption equals a worker's resources which is the sum of after-tax capital income, the return to bonds, and Social Security, $b$. Risky capital income is taxed at rate $\tau^{K}$ and is of the Domar-Musgrave type discussed earlier which taxes only the risky component of investments. Risk-free bond returns are also not taxed; this assumption is always immaterial since the full incidence would fall to the government under the no-arbitrage conditions derived below. 


\section{$\underline{\text { Social Security }}$}

The Social Security benefit is partly pay-as-you-go financed and partly funded. $n_{t+1} \equiv\left(L_{t+1} / L_{t}\right)-1$ equals population growth rate from period $t$ to $t+1$, and $g_{t+1} \equiv\left(w_{t+1} / w_{t}\right)-1$ equals the growth rate in wages. Let $\varphi$ represent the fraction of a generation's Social Security payroll tax that goes to a trust fund, $\mathrm{T}$, which is used to help pay for that same generation's secondperiod Social Security benefit (which is the purpose of pre-funding Social Security); the fraction $(1-\varphi)$ of payroll taxes pays for the benefits of the previous generation. The per-capita Social Security defined benefit is,

$$
\begin{aligned}
b_{t+1} & \equiv\left[(1-\varphi) \tau_{t+1}^{S S} L_{t+1} w_{t+1}+\mathrm{T}_{t+1}\right] / L_{t} \\
& =\left[(1-\varphi) \tau_{t+1}^{S S}\left(1+n_{t+1}\right) w_{t}\left(1+g_{t+1}\right)\right]+\left[\mathrm{T}_{t+1} / L_{t}\right]
\end{aligned}
$$

The expression in the first bracket in the second equality is the stochastic wage-indexed pay-as-yougo portion of Social Security and the expression in the second bracket is the funded portion.

The trust fund holds the part of the payroll tax that does not get paid out immediately as benefits. It is immaterial whether Social Security pays the Treasury taxes on its investments since the defined-benefit liabilities remain unchanged. Let $\phi$ be the fraction of the trust fund invested in equities and, hence, let $(1-\phi)$ be the fraction invested in government debt. The value of the trust fund at $t+1$ equals,

$$
\mathrm{T}_{t+1} \equiv \varphi \tau_{t}^{S S} L_{t} w_{t}\left\{1+\left[\phi e_{t+1}+(1-\phi) \cdot r_{t+1}\right]\right\}+S_{t+1}
$$

where $S$ is a subsidy, from either general revenue or from changing payroll taxes,

$$
\begin{aligned}
S_{t+1} & \equiv \varphi \tau_{t}^{S S} L_{t} w_{t}\left\{r_{t+1}-\left[\phi e_{t+1}+(1-\phi) \cdot r_{t+1}\right]\right\} \\
& =-\varphi \phi \tau_{t}^{S S} L_{t} w_{t}\left(e_{t+1}-r_{t+1}\right)
\end{aligned}
$$

The subsidy, $S$, reflects the risk and expected additional return from investing the trust fund 
in equities. In particular, $S$ equals the difference between what the trust fund would have earned if invested in government debt and what the trust fund actually earns. Currently $\phi=0$ and so $S=0$. The subsidy is positive $(S>0)$ if equity are below the risk-free rate; negative $(S<0)$ otherwise. A negative subsidy (i.e., a "refund" to taxpayers) is expected along the constant productivity growth path where $E_{t}\left(e_{t+1}\right)>r_{t+1} \cdot{ }^{5}$ But this expected benefit to generation $t+1$ comes at a cost of additional risk.

\section{$\underline{\text { First-Order Conditions }}$}

The first-order conditions for the demand for bonds and equities for given tax parameters are,

$$
\beta E\left[\frac{u^{\prime}\left(c_{2, t+1}\right)}{u^{\prime}\left(c_{1, t}\right)}\left(1+r_{t+1}\right)\right]=1
$$

and,

$$
\beta E\left\{\frac{u^{\prime}\left(c_{2, t+1}\right)}{u^{\prime}\left(c_{1, t}\right)}\left[1+e_{t+1}-\left(e_{t+1}-r_{t+1}\right) \tau_{t+1}^{K}\right]\right\}=\beta E\left[\frac{u^{\prime}\left(c_{2, t+1}\right)}{u^{\prime}\left(c_{1, t}\right)}\left(1+e_{t+1}\right)\right]=1
$$

Equation (7) is the standard "intertemporal" condition governing resource allocation over time. Equation (8) is the "portfolio" condition governing the allocation of saving between bonds and equities. ${ }^{6}$ The second equality in equation (8) follows after some algebra and using condition (7). The capital income tax rate falls out of equation (8) due to tax symmetry around the risk-free rate.

\section{Production}

Net output at time $t$ takes the Cobb-Douglas form and is produced using capital, $K$, and labor, $L$, and is also determined by the economy's level of productivity, $A$, and the depreciation rate, $\delta$ :

$$
f\left(k_{t}\right)=A_{t} k_{t}^{\alpha}-\delta_{t} k_{t}
$$

\footnotetext{
${ }^{5}$ This inequality is guaranteed by the production technology shown below.

${ }^{6}$ Both equations must, in general, be solved simultaneously for $s^{B}$ and $s^{K}$, except in special cases.
} 
where $k_{t} \equiv K_{t} / L_{t}$. Both $A$ and $\delta$ are stochastic to allow for an imperfect correlation between wage and capital returns, as in Bohn (1999). Let $A_{t}=\left(1+a_{t}\right) A_{t-1}$ where $a \sim F(\lambda, \underline{a}, \bar{a}, \ldots)$, $\underline{a}<a<\bar{a}$, with $\lambda$ equal to the mean. Moreover, $\delta=\hat{\delta}+\Delta$ where $\hat{\delta}$ is a constant and $\Delta$ is i.i.d. with mean zero.

Stochastic factor prices for wages and the net return to risky capital are neoclassic,

$$
\begin{aligned}
& w_{t}=A_{t}(1-\alpha) k_{t}^{\alpha} \\
& e_{t}=A_{t} \alpha k_{t}^{\alpha-1}-\delta_{t}
\end{aligned}
$$

The neoclassical specification implies that the conditional equity return distribution, $e \sim \Xi(\lambda, k, \ldots)$, as well as the risk-free rate, must be solved jointly with the saving and portfolio decisions. The inequality, $-1<a$, guarantees positive productivity. This Cobb-Douglas specification, although used in the numerical results below, is not necessary for the analytical results. All that is required is that capital is not stochastically dominated by bonds in equilibrium and, therefore, some capital is held. For CD technology, notice that $e \rightarrow \infty$ as $k \rightarrow 0$. Hence, some capital must be held in equilibrium under market clearing (below).

\section{$\underline{\text { Rest of Government }}$}

Government debt as a fraction of the capital stock evolves as follows:

$$
\frac{D_{t+2}}{K_{t+2}}=\frac{\left\{G_{t+1}+S_{t+1}-\left[\tau_{t+1}^{W} L_{t+1} w_{t+1}+\tau_{t+1}^{K} \cdot\left(e_{t+1}-r_{t+1}\right) \cdot L_{t} s_{t}^{K}\right]\right\}+\left(1+r_{t+1}\right) D_{t+1}}{L_{t+2} k_{t+2}} \equiv \widetilde{d}_{t+2}
$$

where $G_{t}=G_{0} \cdot\left(f\left(k_{t}\right) / f\left(k_{0}\right)\right)$ is non-Social Security government spending. Period $t=0$ represents some fixed date, maybe the start of a policy change. Scaling government spending to net output is required to prevent the debt-capital ratio from diverging. Non-Social Security tax rates must also adjust to prevent the debt-capital output from diverging even at small values of government spending 
in the presence of outstanding debt. Without any loss in generality, we assume that tax rates adjust to maintain a constant capital-debt ratio, $\widetilde{d}_{t}=\overline{\widetilde{d}}$. This restriction is imposed only at a low generational frequency and all equivalency results hold if we allowed for a Keynesian debt policy.

Tax revenue at time $t+1$, excluding Social Security contributions, therefore equals the sum of non-Social Security government spending, any subsidy to Social Security, and debt service:

$$
\begin{aligned}
& \tau_{t+1}^{W} L_{t+1} w_{t+1}+\tau_{t+1}^{K} \cdot\left(e_{t+1}-r_{t+1}\right) L_{t} s_{t}^{K}= \\
& \quad G_{t+1}+S_{t+1}+\left(1+r_{t+1}\right) \cdot \overline{\widetilde{d}} \cdot L_{t+1} k_{t+1}-\overline{\widetilde{d}} \cdot L_{t+2} k_{t+2}
\end{aligned}
$$

Equation (13) requires that wage taxes and/or capital income taxes are state contingent. The equivalency results derived below between trust fund investment in equities and capital income taxation, however, does not depend on the exact combination. It can be shown that trust fund investment is actually neutral, even though Social Security is a defined-benefit system, if capital income taxes fully adjust to offset changes in the subsidy, $S$. If capital income taxes do not fully adjust to offset changes in $S$, at least some of the policy risk is passed to future generations through wage taxes.

It is natural, therefore, to assume that only wage taxes will be adjusted to shocks. This assumption allow us to focus on a single capital income tax rate along the stationary and constant productivity growth path that is equivalent to investing the Social Security trust fund in equities. Moreover, this setup would indeed be the case if Social Security payroll tax rates were adjusted to shocks in the value of the trust fund. This approach would maintain Social Security's appearance as a pension system and this approach has been advocated by many proponents of trust fund investment in equities, including six members of the 1994-1996 Social Security Advisory which formed the basis of President Clinton's proposal. Herein, since benefits are defined by law (as in equation (4)), one does not need to distinguish between Social Security payroll taxes and other wage 
taxes. The state contingent wage tax rate equals

$$
\tau_{t+1}^{W}=\frac{G_{t+1}+S_{t+1}+\left(1+r_{t+1}\right) \cdot \overline{\widetilde{d}} \cdot L_{t+1} k_{t+1}-\overline{\widetilde{d}} \cdot L_{t+2} k_{t+2}-\tau_{t+1}^{K} \cdot\left(e_{t+1}-r_{t+1}\right) L_{t} s_{t}^{K}}{L_{t+1} w_{t+1}}
$$

\section{Market Clearing}

Market clearing requires that the capital stock held at time $t$ is equal to the sum of capital held by private agents and the Social Security Administration. Similar is true regarding government debt.

$$
\begin{gathered}
k_{t+1}=\frac{s_{t}^{k}+\phi \varphi \tau_{t}^{S S} w_{t}}{1+n_{t+1}} \\
D_{t+1}=L_{t} s_{t}^{B}+(1-\phi) \varphi \tau_{t}^{S S} L_{t} w_{t}
\end{gathered}
$$

By Walras' Law, the goods-market condition also clears. It can be shown (á la Wang [1993]) that the model produces a globally unique and stable non-degenerate stochastic stationary equilibrium since capital saving at time $t, s_{t}^{K}$, is concave in the capital stock, $k_{t}$, conditional on $a_{t+1} \in\{\underline{a}, \bar{a}\}$. All price distributions and taxes are stationary when shocks take their mean values.

\section{Equivalence Between Trust Fund Investment and Capital Income Taxes}

We start with the following lemma.

Lemma 1. Let $s_{t}^{K^{*}}$ be the per-capita level of capital saving by generation-t agents in the first period of their lives when the capital income tax they face at period two equals $\tau_{t+1}^{K^{*}}$. Suppose the government changes the capital income tax rate to $\tau_{t+1}^{K^{* *}}$. At the pre-reform equity price distribution, $\Xi\left(\lambda, k_{t}^{*}, \ldots\right)$, and risk-free rate, $r_{t+1}^{*}$, the new desired level of capital saving equals

$$
s_{t}^{K^{* * *}}=s_{t}^{K^{*}}\left[\frac{\left(1-\tau^{K^{*}}\right)}{\left(1-\tau^{K^{* *}}\right)}\right]
$$

and the new level of saving in the risk-free asset equals 
Lemma 1 and its proof are similar to that derived in the previous literature and so the proof is relegated to the Appendix. ${ }^{7}$ Lemma 1 is very intuitive. It says that if, for example, the government increased the capital income tax from zero to 50 percent, agents would respond by "doubling their bet" in equities while decreasing their bond holdings dollar for dollar since the government now gets half of the return. From the agent's perspective, tax symmetry implies that a portion of previously risky investments are now risk free which agents perfectly offset in their portfolio.

The following theorem derives the value of the capital income tax that is equivalent, in general equilibrium, to investing some or all of the Social Security trust fund in equities.

Theorem 1. Suppose the government invests some or all of the trust fund in equities (i.e., $\phi>0)$ and let $s_{t}^{K^{*}}$ and $w_{t}$ equal the level of private saving and the wage rate, respectively, in the economy at time t under this policy. This policy can be replicated in general equilibrium by instead increasing the current value of the capital income tax from $\tau_{t+1}^{K^{*}}$ to the following value,

$$
\tau_{t+1}^{K^{* *}}=1-\frac{s_{t}^{K^{*}} \cdot\left[1-\tau_{t}^{K^{*}}\right]}{s_{t}^{K^{*}}+\phi \varphi \tau_{t}^{S S} w_{t}}
$$

\section{Proof of Theorem 1}

To prove equivalency in general equilibrium, both policies must generate the same equilibrium sequence of capital holdings, bond holdings, and state-contingent wage taxes.

(i) Capital. If $\phi>0$ fraction of the trust fund invested in equities at time $t$,

${ }^{7}$ Sandmo $(1977,1985)$ shows that this type of result extends to an arbitrary number of risky assets. In particular, he shows that $\frac{\partial s_{j}}{\partial \tau_{j}}=\frac{s_{j}}{1-\tau_{j}}$ and $\frac{\partial s_{i}}{\partial \tau_{j}}=0(i \neq j)$, where $i$ and $j$ are two different assets. 
$k_{t+1}=\frac{s_{t}^{K^{*}}+\phi \varphi \tau_{t}^{S S} w_{t}}{1+n_{t+1}}$ by equation (15). Suppose instead that $\phi=0$ fraction of the trust fund invested is in equities, and that the capital income tax rate is raised from $\tau_{t+1}^{K^{*}}$ to the value shown in equation (19). Then, by equation (17) of Lemma 1, private saving in capital at time $t$ increases from $s_{t}^{K^{*}}$

to

$$
s_{t}^{K^{* *}}=s_{t}^{K^{*}}+\phi \varphi \tau_{t}^{S S} w_{t}
$$

Hence, $k_{t+1}=\frac{s_{t}^{K^{* *}}}{1+n_{t+1}}=\frac{s_{t}^{K^{*}}+\phi \varphi \tau_{t}^{S S} w_{t}}{1+n_{t+1}}$ by equation (15).

(ii) Bonds. If $\phi>0$ fraction of the trust fund is invested in equities at time $t$, $D_{t+1}=L_{t} s_{t}^{B^{*}}+(1-\phi) \varphi \tau_{t}^{S S} L_{t} w_{t}$, by equation (16). Suppose instead that $\phi=0$ fraction of the trust fund invested is in equities, and that the capital income tax rate is raised from $\tau_{t+1}^{K^{*}}$ to the value shown in equation (19). Then, by equation (18) of Lemma 1, private saving in bonds at time $t$ $\begin{array}{lllllllllllllllllllllll}\mathrm{d} & \mathrm{e} & \mathrm{c} & \mathrm{r} & \mathrm{e} & \mathrm{a} & \mathrm{s} & \mathrm{e} & \mathrm{s} & & \mathrm{f} & \mathrm{r} & \mathrm{o} & \mathrm{m} & & s_{t}^{B^{*}} & \mathrm{t} & \mathrm{o} & s_{t}^{B^{* *}}=s_{t}^{B^{*}}-\phi \varphi \tau_{t}^{S S} w_{t} .\end{array}$ Hence, $D_{t+1}=L_{t} s_{t}^{B^{* *}}+\varphi \tau_{t}^{S S} L_{t} w_{t}=L_{t} s_{t}^{B^{*}}+(1-\phi) \varphi \tau_{t}^{S S} L_{t} w_{t}$.

(iii) State-contingent wage taxes. If $\phi>0$ fraction of the trust fund is invested in equities at time $t$, equations (6) and (14) imply

where

$$
\tau_{t+1}^{W}=\frac{G_{t+1}+S_{t+1}+\left(1+r_{t+1}\right) \cdot \overline{\widetilde{d}} \cdot L_{t+1} k_{t+1}-\overline{\widetilde{d}} \cdot L_{t+2} k_{t+2}-\tau_{t+1}^{K^{*}} \cdot\left(e_{t+1}-r_{t+1}\right) L_{t} s_{t}^{K^{*}}}{L_{t+1} w_{t+1}}
$$

$$
S_{t+1}=-\varphi \phi \tau_{t}^{S S} L_{t} w_{t}\left(e_{t+1}-r_{t+1}\right)
$$

If instead $\phi=0$ fraction of the trust fund invested is in equities, and that the capital income tax rate is raised from $\tau_{t+1}^{K^{*}}$ to the value shown in equation (19). Then $S_{t+1}=0$ and equation (14) gives,

$$
\begin{aligned}
\underset{\tau_{t+1}^{W}}{(23)} & =\frac{G_{t+1}+\left(1+r_{t+1}\right) \cdot \overline{\widetilde{d}} \cdot L_{t+1} k_{t+1}-\overline{\widetilde{d}} \cdot L_{t+2} k_{t+2}-\tau_{t+1}^{K^{* *}} \cdot\left(e_{t+1}-r_{t+1}\right) L_{t} s_{t}^{K^{* *}}}{L_{t+1} w_{t+1}} \\
& =\frac{G_{t+1}+\left(1+r_{t+1}\right) \cdot \overline{\widetilde{d}} \cdot L_{t+1} k_{t+1}-\overline{\widetilde{d}} \cdot L_{t+2} k_{t+2}-\left[1-\frac{s_{t}^{K^{*}} \cdot\left(1-\tau_{t}^{K^{*}}\right)}{s_{t}^{K^{*}}+\phi \varphi \tau_{t}^{S S} w_{t}}\right] \cdot\left(e_{t+1}-r_{t+1}\right) L_{t}\left(s_{t}^{K^{*}}+\phi \varphi \tau_{t}^{S S} w_{t}\right)}{L_{t+1} w_{t+1}} \\
& =\frac{G_{t+1}+S_{t}+\left(1+r_{t+1}\right) \cdot \overline{\widetilde{d}} \cdot L_{t+1} k_{t+1}-\overline{\widetilde{d}} \cdot L_{t+2} k_{t+2}-\tau_{t+1}^{K^{*}} \cdot\left(e_{t+1}-r_{t+1}\right) L_{t} s_{t}^{K^{*}}}{L_{t+1} w_{t+1}}
\end{aligned}
$$


The second equality in equation (23) stems from substituting equations (19) and (20) into the first equality in (23). The third equality in equation (23) comes re-arranging the second equality and using equation (20). In can be readily seen that the third equality is equal to the expression shown in equation (21).

Q.E.D.

\section{Interpretation of Theorem 1}

The equivalency result shown in Theorem 1 demonstrates that a single tax change on capital income can be used to exactly replicate all state-contingent market quantities, prices and tax rates stemming from investing the trust fund in equities. All markets clear at the same pre-tax prices simply by changing the capital income tax rate. Only the after-tax return to capital is different. But it is important to note what Theorem 1 does not say: as shown in the calculations below, trust fund investment in equities is not neutral.

As referenced in Section I, some previous work demonstrates that investing the Social Security trust fund in equities could improve efficiency in the presence of various market failures. Theorem 1, though, gives a "decentralized way" of investing the trust fund in equities. In essence, the capital income tax acts like a Lindahl price mechanism that can be used to correct market failures without direct government control.

\section{Numerical Calculations}

This section presents simulation evidence of the capital income tax rate that replicates a proposal to invest the entire Social Security trust fund in equities.

Solving the Model

Several variables must be determined simultaneously in general equilibrium. The equity 
return distribution, $\Xi(\lambda, k, \ldots)$, and the risk-free rate must be determined jointly with the saving and portfolio decisions of agents in order to satisfy the general-equilibrium conditions, (15) and (16). The state-contingent tax wage tax rate, (14), must be part of this equation set since the level of debt passed to future generations depends on the amount of private capital saving. The system of equations must also include the return to the pay-as-you portion of Social Security since benefit payments are indexed to stochastic wage growth (equation (4)), which is dependent on the amount of endogenous capital saving. The return to the funded portion of Social Security must also be included in this equation set because its return is a linear combination of bond and stock returns, both of which also depend on the amount of endogenous capital saving.

The numerical solution to the model herein is further complicated by the fact the model allows for shocks to both productivity and depreciation in order to allow for an imperfect correlation between wage and capital returns. Since Social Security benefits are waged indexed, agents are exposed to productivity shocks through their pay-as-you-go Social Security benefits. That exposure, in turn, endogenously affects their portfolio demand and, in particular, tends to reduce their demand for stocks.

The model is algebraically reduced and then solved using a multi-variate Newton method (other methods proved unstable). If more periods of life were added to the model, this technique could not be used and an exact solution would not be possible. ${ }^{8}$ More periods are possible with idiosyncratic risk but that type of risk implies that future prices are known. With aggregate uncertainty, as herein, adding more periods creates a "curse of dimensionality." Current approximations are known to be unreliable and cannot generate a realistic equity premium. To the

\footnotetext{
${ }^{8}$ Approximation methods for multiple-period models with aggregate uncertainty are still in their infancy and current heuristic approaches are known to be unreliable. The model herein is solved using Maple V software. The model is first reduced symbolically and then solved numerically to 30 digits precision.
} 
best of my knowledge, this model is the first to exactly solve a stochastic overlapping-generations lifecycle model with a fully endogenous equity return distribution and risk-free rate. The other endogenous factors mentioned above add to the model's richness.

Previous papers on trust fund investment in equities avoided these complications by focusing on partial equilibrium results, or by simplifying preferences, technology and social security rules. Bohn (1999) considers a two-period partial-equilibrium model in order to focus on marginal changes to the trust fund investment policy. Abel (2000) considers a two-period general-equilibrium model with log utility. Stock returns are exogenous which he motivates with a non-neoclassical production technology subject to a single productivity shock. For simplicity, his model treats Social Security as a fully-funded defined contribution system which also abstracts away from the correlation between wage-indexed Social Security benefits and equity returns considered herein. Abel's model also focuses marginal changes in the trust fund portfolio for a single period. Diamond and Geanakoplos (1999) consider a two-period model with workers who have only labor income and capitalists who only have capital income. Technology is linear and so stock returns are exogenous and uncorrelated with social security benefits. The risk-free rate is endogenous in their model and they also simplify by assuming that Social Security takes the defined-contribution form.

\section{$\underline{\text { Calibration }}$}

Utility takes the constant relative risk averse form, $E_{t} U_{t}=\frac{1}{1-\gamma}\left[c_{1, t}^{1-\gamma}+\beta E_{t}\left(c_{2, t+1}^{1-\gamma}\right)\right]$, where $\gamma$ is the coefficient of relative risk aversion and $\beta=1 /(1+\rho)$, where $\rho$ is the time preference. Productivity is a two-state Markov process, $A_{t}=A_{t-1} \cdot(1+\lambda) \cdot\left(1+a_{t}\right)$, where $\lambda$ is trend growth and $a_{t}$ is a mean-zero stochastic shock, $a_{t} \in\{\chi,-\chi\}$, that can take the values $\chi$ and (- $\left.\chi\right)$ with equal probability, $\chi<1$. Depreciation is stochastic, $\delta=\hat{\delta}+\Delta$, with $\Delta \in\{\varepsilon,-\varepsilon\}$. Labor supply growth is constant, $n_{t}=n$. As in several previous models, each period is taken to represent 30 years, or 
about one generation.

Calibrating the model requires choosing the parameter vector $\left\{k_{0}, A_{0}, \delta_{0}, \lambda, \gamma, \beta, \chi, \varepsilon, n, \varphi\right\}$ to match various baseline economic relationships shown in Table 1. The process entails "inverting" the aforementioned system of equations to express these parameters as a function of observable economic variables. The resulting parameter vector is unique. Additional details are provided in the Appendix.

\section{$\underline{\text { Simulation Results }}$}

Table 2 reports the capital income tax rates for the next five generations (representing 150 years) that replicates investing the entire Social Security trust fund in equities $(\phi=1)$. Table 2 also reports the impact of trust fund investment in equities on macroeconomic variables during the transition from the initial (pre-reform) stochastic steady state to the final stochastic steady state. State variables are updated between generations conditional on productivity and depreciation shocks taking their mean values ex post. ${ }^{9}$

Notice that trust fund investment can be replicated by increasing the capital income tax rate from its current value of 20 percent to 24 percent over the long run. These new tax rates incorporate the effects that the policy change has on the risk-free rate and the equity price distribution that result from changes in the capital-labor ratio. Notice that the annual risk-free rises by 20 basis in the long run and the annual equity premium falls by 30 basis points as the government shifts from bonds to equities. Wage tax rates also fall due the negative subsidy $S$ along the constant productivity growth path. The negative subsidy leads to an increase in future after-tax wages and capital in the long run, as also shown by Abel (1999).

\footnotetext{
${ }^{9}$ Each possible path of future shocks generates different equivalent tax rate paths. The earlier formulae and the equivalency of both policy reforms hold for all possible paths.
} 


\section{Endogenous Heterogeneity in Portfolio Choice and Saving}

Almost half of US households are not exposed to stocks, either through retirement plans or other forms of saving. Most on these same households appear to hold very little non-housing wealth as well. This section introduces this type of heterogeneity endogenously by enforcing the legal restriction that prohibits borrowing against future Social Security benefits. ${ }^{10}$ Two types of agents are considered: type- $L$ agents with low first-period wages and type- $H$ agents with high first-period wages. Type- $L$ agents may endogenously become borrowing constrained in equilibrium. The equivalence between trust fund investment in equities and capital income taxation, though, still holds. Simulation results are also reported.

\section{Extending the Model}

Consider $L_{t}^{L}$ number of type- $L$ laborers with low wages and $L_{t}^{H}$ number of type- $H$ laborers with high wages. As before, $L_{t}$ is the total size of the labor force at time $t, L_{t}=L_{t}^{L}+L_{t}^{H}$. The model is extended to include agent heterogeneity by re-defining per-capita variables as average percapita variables and then stating how average per-capital amounts are divided between the different agents.

Let $\zeta=L_{t}^{L} / L_{t}$ represent type- $L$ 's share of the labor force at time $t$ which, without loss in generality, is taken as constant over time. Hence, $(1-\zeta)=L_{t}^{H} / L_{t}$. The per-capita wage of agent type $i \in\{L, H\}$ is $w_{t}^{i}=\xi^{i} w_{t}$. The variable $\xi^{i}$ represents agent $i$ 's productivity scale relative to the average wage, $w_{t}=\zeta \cdot w_{t}^{L}+(1-\zeta) w_{t}^{H}$, which is given by equation (10). Hence,

$$
\xi^{H}=\frac{1-\zeta \cdot \xi^{L}}{1-\zeta}
$$

\footnotetext{
${ }^{10}$ In the United States and some other countries, it is illegal to use Social Security benefits as collateral.
} 
Notice that $\xi^{H}=\xi^{L} \Leftrightarrow \xi^{L}=1$ (wage equality) and $\xi^{H}>\xi^{L} \Leftrightarrow \xi^{L}<1$ (inequality). Total labor income at time $t$, therefore, equals $L_{t} w_{t}$.

Wage tax rates are allowed to be progressive. Denote the state-contingent wage tax rate of agent $i$ as $\tau_{t}^{w^{i}}=v^{i} \tau_{t}^{w}$. The variable $v^{i}$ represents agent $i$ 's tax rate relative to the average wage tax rate, $\tau_{t}^{w}=\zeta \cdot \tau_{t}^{w^{L}}+(1-\zeta) \tau_{t}^{w^{H}}$, given by equation (14). It follows that,

$$
v^{H}=\frac{1-\zeta \cdot v^{L}}{1-\zeta}
$$

Note that $v^{H}=v^{L} \Leftrightarrow v^{L}=1$ (linear tax rates) and $v^{H}>v^{L} \Leftrightarrow v^{L}<1$ (progressive tax rates).

Similarly, agent $i$ 's Social Security benefit equals $b_{t}^{i}=\eta^{i} b_{t}$. The variable $\eta^{i}$ is agent $i$ 's Social Security benefit relative to the average benefit, $b_{t}=\zeta \cdot b_{t}^{L}+(1-\zeta) b_{t}^{H}$, given by equation (14). Hence,

$$
\eta^{H}=\frac{1-\zeta \cdot \eta^{L}}{1-\zeta}
$$

The benefit received by agent $i$ is proportional to previous payroll taxes paid by agent $i$ if $\eta^{i}=\xi^{i}$. In this case, each agent receives the same replacement rate on their first-period wages. Social Security benefits are deemed progressive if $\eta^{H}<\xi^{H}$, which by equations (26) and (24), implies $\eta^{L}>\xi^{L}$. Type- $H$ agents now receive a replacement rate on their wages that is lower than type- $L$ 's replacement rate.

The agent's optimization problem, with the agent index $i \in\{L, H\}$, becomes,

$$
\max _{s_{t}^{B^{i}}, s_{t}^{K^{i}}} E_{t} U\left(c_{1, t}^{i}, c_{2, t+1}^{i}\right)=u\left(c_{1, t}^{i}\right)+\beta E_{t} u\left(c_{2, t+1}^{i}\right)
$$

subject to the following budget constraints, ${ }^{11}$

\footnotetext{
${ }^{11}$ The tax rate on capital income follows convention and is modeled as proportional. When type- $L$ agents are borrowing constrained, they don't face that tax anyway.
} 


$$
\begin{gathered}
c_{1, t}^{i}+s_{t}^{K^{i}}+s_{t}^{B^{i}}=\xi^{i} w_{t}\left(1-\tau_{t}^{S S}-v^{i} \tau_{t}^{W}\right) \\
c_{2, t+1}^{i}=s_{t}^{K^{i}} \cdot\left[1+e_{t+1}-\left(e_{t+1}-r_{t+1}\right) \tau_{t+1}^{K}\right]+s_{t}^{B^{i}} \cdot\left(1+r_{t+1}\right)+\eta^{i} b_{t+1}
\end{gathered}
$$

where

$$
s_{t}^{K^{i}}+s_{t}^{B^{i}} \geq 0
$$

Equation (30) enforces the legal restriction prohibiting borrowing against second-period Social Security benefits. The first-order conditions are

$$
\beta E\left[\frac{u^{\prime}\left(c_{2, t+1}^{i}\right)}{u^{\prime}\left(c_{1, t}^{i}\right)}\left(1+r_{t+1}\right)\right]=\beta E\left[\frac{u^{\prime}\left(c_{2, t+1}^{i}\right)}{u^{\prime}\left(c_{1, t}^{i}\right)}\left(1+e_{t+1}\right)\right]=\widetilde{\boldsymbol{\mu}}_{t}^{i}
$$

where $\widetilde{\mu}_{t}^{i} \equiv 1-\mu / u\left(c_{1, t}^{i}\right)$ and $\mu$ is the Lagrangian multiplier for restriction (30). $\widetilde{\mu}^{i}<1$ if equation (30) binds for agent $i$; otherwise, $\widetilde{\mu}^{i}=1$. Now interpreting $s_{t}^{K}$ as the average per-capita saving in capital, $s_{t}^{K}=\zeta \cdot s_{t}^{K^{L}}+(1-\zeta) s_{t}^{K^{H}}$, and $s_{t}^{B}$ as average per-capita saving in bonds, the rest of the formulae shown in Section II, for the government sector and market clearing, remain the same.

Lemma 2. Let $\Omega=\left\{\left(\xi^{L}, v^{L}, \eta^{L}\right) \mid \xi^{L}<1, v^{L} \leq 1, \eta^{L} \geq \xi^{L}\right\}$ be the set of parameter tuples $\left(\xi^{L}, v^{L}, \eta^{L}\right)$, i.e., the set of parameters generating wage inequality along with non-regressive wage taxes and non-regressive social security benefits. Then,

(i) Let $\widetilde{\Omega}_{t}=\left\{\sigma \in \Omega \mid \widetilde{\mu}_{t}^{L}<1\right\}$ be the subset of $\Omega$ where, for each parameter tuple, the type- $L$ agent is endogenously borrowing constrained at time t. Then $\# \widetilde{\boldsymbol{\Omega}}_{t}>0$ (i.e., the subset is not empty) under the Inada condition $\lim _{c \rightarrow 0} \partial u(c) / \partial c=\infty$ and with positive productivity, $A>0$.

(ii) $\tilde{\mu}^{H}(\sigma)=1 \forall \sigma \in \Omega$ when $\phi=0$, i.e., the type-H agent is not endogenously borrowing constrained for any parameter vector in $\Omega$ before the trust fund invests in equities .

Proof. [Parti] To show $\# \widetilde{\boldsymbol{\Omega}}_{t}>0$, note that for any value $\eta^{L} \geq 1, \xi^{L} \rightarrow 0 \Rightarrow c_{1, t}^{L} \rightarrow 0$ under the borrowing constraint shown in equation (27) while $c_{2, t+1}^{L}$ is strictly bounded above zero by the 
budget constraint (29). Hence, $\widetilde{\mu}^{L}<1$ by equation (28). [Part ii] Consider first the sub-case in which $\sigma \in \widetilde{\Omega}_{t}$. Supposethat $\widetilde{\mu}^{H}(\sigma)<1$ and $\widetilde{\mu}^{L}(\sigma)<1$. Then $\phi=0 \Rightarrow k=0$ byequation $(15) \Rightarrow e \rightarrow \infty$ by equation (11), thereby contradicting $\widetilde{\mu}^{i}<1$ by equation (28). Now consider the sub-case in which $\sigma \in \widetilde{\Omega}_{t}^{C}$. Then $\widetilde{\mu}^{H}(\sigma)<1 \Rightarrow \widetilde{\mu}^{L}(\sigma)<1 \forall \sigma \in \Omega$ which contradicts $\sigma \in \widetilde{\Omega}_{t}^{C}$.

Q.E.D.

It follows that type- $L$ agents will choose to be borrowing constrained if we pick the parameter vector, $\sigma \in \Omega$, in the non-empty set $\widetilde{\Omega}_{t}$ at time $t$, before the Social Security invests in equities (part i). But type- $H$ agents will not be borrowing constrained (part ii). We now arrive at the following key theorem:

Theorem 2. Let $s_{t}^{K^{*}}=\zeta \cdot s_{t}^{K^{L^{*}}}+(1-\zeta) s_{t}^{K^{H^{*}}}$ equal the average per-capita level of capital saving and let $w_{t}^{*}=\zeta \cdot w_{t}^{L^{*}}+(1-\zeta) w_{t}^{H^{*}}$ equal the average wage rate at time $t$ after the trust fund is invested in equities. If type-L agents are endogenously borrowing constrained $\left(\sigma \in \widetilde{\Omega}_{t}\right)$ or not $\left(\sigma \in \widetilde{\Omega}_{t}^{C}\right)$, the trust fund policy to invest in equities can be replicated by instead increasing the value of the capital income tax from its current value to the value shown in equation (19) of Theorem 1.

\section{$\underline{\text { Discussion }}$}

The proof for Theorem 2 is same as that for Theorem 1 along with our interpretation of relevant lowercase variables as representing their per-capita average values. For a choice of the parameter vector $\sigma \in \widetilde{\Omega}_{t}^{C}$, neither agent is borrowing constrained. For $\sigma \in \widetilde{\Omega}_{t}$, however, type- $L$ agents are borrowing constrained before the trust fund is invested in equities and type- $H$ agents are not constrained. In this case, the tax-induced portfolio adjustment made by only type- $H$ agents clear the capital and bond markets, and generate the same individual wage tax rates, $\tau_{t+1}^{W^{i}}(i \in\{L, H\})$, at the same market prices as trust fund investment in equities. Type- $L$ agents are the same under both 
policies since they face the same state-contingent wage tax rate under both policies. Remember that Theorems 1 and 2 demonstrate the equivalency of two fiscal policies. Neither theorem claims that investing the trust fund in equities is itself neutral relative to no investment in the presence of incomplete markets between and within generations.

The equivalence of trust fund investment in equities and capital income taxes is quite general. First, it does not matter if, for example, $\sigma \in \widetilde{\Omega}_{t}$ and $\sigma \in \widetilde{\Omega}_{t+1}^{C}$, i.e., if the type- $L$ agent is borrowing constrained at time $t$ and not constrained at time $t+1$. In other words, the equivalence of the two fiscal policies does not require that the economy move along some mean path inside of a broader stochastic steady state. The equivalence holds even outside of stochastic steady state.

Second, the equivalence does not require any additional portfolio restriction on the type- $L$ agent. The borrowing constraint shown in equation (30) does not, for example, rule out the type- $L$ agent wanting to hold no equities or even a short position in equities along with a long position in bonds. A type- $L$ agent might want to hold zero or negative amounts of stocks in the presence of productivity shocks which cause their wage-indexed Social Security benefits to be highly correlated with stock returns. This correlation has not been captured in previous models, which instead have relied on large ad-hoc fixed costs or equivalent mechanisms to limit market participation. ${ }^{12}$

\section{$\underline{\text { Simulation Results }}$}

For most parameter vector choices in the stable set $\widetilde{\Omega}_{t}$ along the mean path, the inclusion of endogenously borrowing-constrained type- $L$ agents into the model has little impact on the numerical calculations. Obviously, the importance of including type- $L$ agents approaches zero as their wage share, $\xi^{L}$, of average wage income approaches zero. To established an upper bound on the role of

\footnotetext{
${ }^{12}$ The fixed cost approach will result in different macroeconomic outcomes. The reason is that with large fixed investment and utility costs (as in Abel, 2000), trust fund investment in equities generates wealth effects. These wealth effects do not occur when agents freely choose no stock holdings due to a correlation with other retirement resources.
} 
type- $L$ agents, the parameter $\xi^{L}$, therefore, was chosen equal to unity, the maximum value possible before the type- $L$ agent switches pre-tax resource rankings with the type- $H$ agent. The parameters $v^{L}$ and $\eta^{L}$ were also set at unity, which is their maximum possible values before type- $L$ and type- $H$ agents switch rankings on a post-fisc basis (i.e., after taxes and transfers). To force type- $L$ agents to be endogenously borrowing constrained throughout the transition, their time preference is set higher than that of type- $H$ agent. ${ }^{13}$

Calibrating to the same economy as before requires larger per-capita saving by unconstrained savers (in both capital and debt) to achieve the same capital-labor ratio. The reason is that inclusion of borrowing constrained type- $L$ agents adds to the size of the labor force without a proportional increase in the size of the capital stock. As discussed in the Appendix, the re-calibrated value of $\beta$ (for type- $H$ agents) increased slightly while the re-calibrated value of $\gamma$ decreased slightly. Both economies are otherwise identical.

As shown in Table 2, the policy-equivalent capital income tax rates reported in Section IV do not change much when type- $L$ agents are added to the model as half of the population $(\zeta=1 / 2)$, although the changes in the capital stock, national income and risk-free rate are larger. The largest difference between the two model versions is in the risk-free rate which increases by 120 basis points in the long run after the trust fund is invested in equities, versus by just 17 basis points with the single-agent model.

The differences in changes in macroeconomic variables between the two models reflect that the fact that constrained type- $L$ agents have a non-trivial wage income when $\xi^{L}=1$. Before trust fund investment in equities, some of their payroll taxes were invested by Social Security into

\footnotetext{
${ }^{13}$ Although changing type- $L$ 's time preference rate is a mechanical way of generating the maximum impact of endogenously binding borrowing constraints, this approach also has a priori merit. Indeed, one reason why some people might be poor is due to their relative impatience in accumulating physical capital. Social Security, therefore, plays a tangible role herein by providing the poor with retirement income. I am grateful to Peter Diamond for this insight.
} 
government bonds; now they are invested into equities. By construction, the same amount of debt is released by Social Security in both models after the trust fund is invested into equities. But, relative to the single-agent model, unconstrained type- $H$ agents now compose only half of the economy. Hence, they require a larger increase in the risk-free rate in order to hold all the newly released debt. Their portfolio shift, stemming from trust fund investment, does not crowd out as much of their capital saving either, allowing for a larger net increase in aggregate capital. The capital stock is now $8 \frac{1}{2}$ percent larger in the long run versus just $4 \frac{1}{2}$ percent in the single-agent model. National income, therefore, now increases by $2 \frac{1}{2}$ percent instead of by 1.2 percent. Notice that the increased cost of government borrowing drives up wage tax rates over time despite a negative subsidy $(S<0)$ along the mean path. However, notice that the capital income tax rate which is equivalent to trust fund investment is almost identical across the two models. The reason is that a similar change in the capital income tax rate shifts the equity-bond portfolio mix of unconstrained agents by the same amount in both models - i.e., the difference in price effects between the models is not materially important for the tax rate.

\section{Conclusions}

This paper proves that the policy of investing some or all of the Social Security trust fund in equities can be replicated with a simple linear tax on risky capital income. This equivalence is quite general and holds with incomplete markets between generations and even if many agents are endogenously borrowing constrained. Both of these market frictions renders trust fund investment in equities non-neutral. The equivalent tax rate can be interpreted as a Lindahl tax that generates a decentralized approach to achieve the same outcome as the command economy. To the extent that the current US tax on capital income is symmetric and that a tax on the small risk-free rate is 
unimportant (as, for example, argued in Gordon, 1985), then investing the Social Security trust fund in equities can be replicated by simply increasing the existing capital income tax rate - by about 4 percentage points along the constant productivity growth path. To the extent that these tax provisions do not approximately hold for a particular country, implementing the tax provisions in addition to choosing the right tax rate can be used to substitute for direct control of assets by the Social Security system. 


\section{References}

1994-1995 Advisory Council on Social Security, The. Findings, Recommendations, and Statements. The United States Social Security Administration, Washington, DC, 1997.

Abel, Andrew. "The Social Security Trust Fund, the Riskless Interest Rate, and Capital Accumulation." NBER Working Paper \#6991, 1999. Forthcoming in Risk Aspects of Investment-Based Social Security Reform, Campbell, John and Martin Feldstein, eds., Chicago: University of Chicago Press.

Abel, Andrew. "The Effects of Investing Social Security Funds in the Stock Market When Fixed Costs Prevent Some Households from Holding Stocks.” NBER Working Paper \#7739, 2000. Forthcoming in the American Economic Review.

Auerbach, Alan J., "Tax Reform, Capital Accumulation, Efficiency, and Growth," in Henry J. Aaron and William G. Gale, eds., Economic Effects of Fundamental Tax Reform, The Brookings Institution: Washington, D.C., 1996, 29-81.

Auerbach, Alan J., Laurence Kotlikoff, Jagadeesh Gokhale. "Generational Accounting: A Meaningful Way to Evaluate Fiscal Policy." Journal of Economic Perspectives, (8), 1 (Winter 1994): 73-94.

Barro, Robert J. “Are Government Bonds Net Wealth?,” Journal of Political Economy, 82, 6, 1974: $1095-1117$.

Bohn, Henning. "Should the Social Security Trust Fund hold Equities? An Intergenerational Welfare Analysis.” Review of Economic Dynamics, vol.2, no.3, July 1999, 666-697.

Bradford, David. "Consumption Taxes: Some Fundamental Transition Issues." NBER Working Paper No. 5290, 1995.

Congressional Budget Office. "The Economic and Budget Outlook: An Update” July 1, 1999.

Diamond, Peter. "Macroeconomic Aspects of Social Security Reform." Brookings Papers on Economic Activity; 0(2), 1997, pages 1-66.

Diamond, Peter and John Geanakoplos. "Social Security Investment in Equities I: Linear Case." NBER Working Paper \#7103, 1999.

Domar, E. and R. Musgrave. "Proportional Income Taxation and Risk Sharing." Quarterly Journal of Economics, 1944, 58, 388 - 422.

Feldstein, Martin. "Social Security, Induced Retirement, and Aggregate Capital Accumulation." Journal of Political Economy, 85, 5, 1974: 905-926. 
Feldstein, Martin and Andrew Samwick. "The Economics of Prefunding Social Security and Medicare Benefits." in B. Bernanke and J. Rotemberg (eds.) NBER Macroeconomics Annual 1997. Cambridge: MIT Press, 115-148.

Geanakoplos, John, Olivia S. Mitchell and Stephen P. Zeldes. "Would a Privatized Social Security System Really Pay a Higher Rate of Return?” Wharton Financial Institutions Center Paper \#98-26, August, 1998.

Gordon, Roger. "Taxation of Corporate Capital Income: Tax Revenues versus Tax Distortions." Quarterly Journal of Economics, 1985, 100, 1 - 27.

Miller, Merton and Charles Upton. Macroeconomics: A Neoclassical Introduction, First Edition, University of Chicago Press: Chicago, 1974.

Mossin, J. “Taxation and Risk-Taking: An Expected Utility Approach,” Economica, 1968, 35, 74 82.

Poterba, James. "The Rate of Return to Corporate Capital and Factor Shares: New Estimates Using Revised National Income Accounts and Capital Stock Data." NBER Working Paper, 6263, 1998.

Rangel, Antonio. "Forward and Backward Intergenerational Goods: A Theory of Intergenerational Exchange.” NBER Working Paper \#7518, 2000.

Sandmo, Agnar. "Capital Risk, Consumption, and Portfolio Choice," Econometrica, 1969, 37, 586599.

Sandmo, Agnar. "Portfolio Theory, Asset Demand and Taxation: Comparative Statics with Many Assets," Review of Economic Studies, 1977, 44, 369 - 379.

Sandmo, Agnar. "The Effects of Taxation on Savings and Risk Taking." in A.J. Auerbach and M. Feldstein, eds., Handbook of Public Economics, Vol I., 1985, 265 - 311.

Schieber, Sylvester and John Shoven. The Real Deal: The History and Future of Social Security. Yale University Press, 1999.

Smetters, Kent. “Trading with the Unborn: A New Perspective on Capital Income Taxation.” Mimeo, University of Pennsylvania, 2000.

Stiglitz, Joseph. "The Effects of Income, Wealth and Capital Gains Taxation on Risk-Taking." Quarterly Journal of Economics, 1969, 83, 262 - 283.

Wang, Y. "Stationary Equilibria in an Overlapping Generations Economy with Stochastic Production." Journal of Economic Theory, 61, 1993, 423 - 435. 


\section{Appendix}

\section{Proof of Lemma 1}

The absence of the capital income tax in the first-order conditions implies that the consumer's first-period consumption and the ex-post second-period consumption are both invariant to the capital i n c o m e t a x rate. I. e., $s_{t}^{K^{* *}}=s_{t}^{K^{*}}+\Delta, \quad s_{t}^{B^{* *}}=s_{t}^{B^{*}}-\Delta \quad$ a n d $s_{t}^{K^{*}}\left[1+e_{t+1}-\left(e_{t+1}-r_{t+1}\right) \tau_{t+1}^{K^{*}}\right]+s_{t}^{B^{*}}\left(1+r_{t+1}\right)=s_{t}^{K^{* *}}\left[1+e_{t+1}-\left(e_{t+1}-r_{t+1}\right) \tau_{t+1}^{K^{* *}}\right]+s_{t}^{B^{* *}}\left(1+r_{t+1}\right)$. Combining these three equations gives Lemma 1.

\section{Calibration}

The economy at time 0 to be targeted has the following characteristics, with each period representing 30 years. The expected annual depreciation equals 5 percent so that 79 percent of the capital stock is expected to be depreciated by the end of the 30 -year period. The capital share, $\alpha$, is set at 0.30 . The arbitrary scaling parameter $A_{0}$ equals unity.

Based on Poterba (1998) and Ibbotson data, the annual pre-tax (social) real rate of return to capital equals $8 \frac{1}{2}$ percent per year, or 1,056 percent over 30 years, with a coefficient of variation equal to 0.87 . The annual risk-free real return, $r_{1}$, equals 3 percent, or 143 percent over 30 years, based on historic returns to long-term government securities this century. (Notice that the 30-year expected return to equities is about seven times that of bonds.) The annual expected rate of laboraugmenting technological progress is set at 3 percent per year, the average growth rate of the total salaries and wage base since 1929, based on Bureau of Economic Analysis data. The point-estimate correlation between wage and stock returns at a 30 -year frequency is about three-quarters. ${ }^{14}$ The defended debt-capital ratio, $\widetilde{d}$, is set at 0.25 , close to the current ratio of government debt relative to the domestically-owned capital stock as measured in the Federal Reserve Board's Flow of Funds Accounts.

The initial tax rate on the generation- 0 agent's second-period capital income, $\tau_{1}^{K}$, equals 0.20 , following Auerbach (1996). The initial proportional tax rate on wage income, $\tau_{0}^{W}$, is set at 0.15 which generates a plausible level of tax revenue derived from wages. The workforce size relative to retirees, averaged over the past decade and over projections for the next two decades, is constant. The Social Security payroll tax is set at 12 percent and the estimated ratio of contributions to the Social Security trust fund divided by benefits paid during the past and next few decades equals about 4 percent.

The calibrating vector needed to generate this baseline economy, $\left\{k_{0}, A_{0}, \delta_{0}, \lambda, \gamma, \beta, \chi, \varepsilon, n\right.$, $\varphi\}$, equals $\{.0056,1.0,0.79,0.860,0.857,0.27,0.61,6.07,0.0,0.04\}$. The value $\beta=0.27$ corresponds to an annual rate of time preference equal to 4.4 percent. The value of $\gamma=0.857$ reflects scaling the model to equity returns (rather than consumption) as well as both human capital depreciation in the second period and the correlation of wage-indexed pay-as-you-go Social Security returns with stock returns. When the model was re-calibrated to include type- $L$ agents, $\{\beta, \gamma\}$ changed to $\{0.39,0.67\}$.

This calibration generates additional plausible observable economic relationships. The implied net national saving rate equals 4.4 percent. The non-Social Security part of government spending equals 15.3 percent which is very close to the value of $15 \frac{1}{2}$ percent that the CBO (1999) reports for 1998. Capital income tax revenue equals 4.4 percent of GDP while wage income taxes,

${ }^{14}$ To be sure, this point estimate is associated with a large standard error. However, the equivalent tax rates estimated herein were fairly robust to changes in the correlation. 
not including Social Security payroll taxes, compose $10 \frac{1}{2}$ percent of GDP. 


\section{Table 1}

Parameters and Implied Values along Mean Path in the Initial Stochastic Steady State (I.e., Before the Social Security Trust Fund is Invested in Equities)

\begin{tabular}{|c|c|}
\hline Variable Description & Value \\
\hline \multicolumn{2}{|c|}{ Exogenous Parameters (same in all simulations, unless indicated otherwise) } \\
\hline Average annual depreciation rate, $\overline{\hat{\delta}}_{\text {апnиаl }}$ & $5 \%$ \\
\hline Capital share, $\alpha$ & 0.30 \\
\hline Arbitrary Scaling of the Initial Productivity, $A_{0}$ & 1.00 \\
\hline $\begin{array}{l}\text { Pre-tax } 30 \text {-year return to equities on mean path, } \overline{E\left(e_{1} \mid k_{1}\right)} \\
\text { (Corresponding annual return) }\end{array}$ & $\begin{array}{l}1,056 \% \\
(8.5 \%)\end{array}$ \\
\hline Coefficient of Variation, $\bar{\sigma}_{e} / \overline{E\left(e_{1} \mid k_{1}\right)}$ & 0.87 \\
\hline $\begin{array}{l}\text { Pre-tax 30-year risk-free real return on mean path, } r \\
\text { (Corresponding annual return) }\end{array}$ & $\begin{array}{l}143 \% \\
(3 \%)\end{array}$ \\
\hline $\begin{array}{l}\text { Rate of } 30 \text {-year labor-augmenting tech. progress, } \lambda \\
\text { (Corresponding annual return) }\end{array}$ & $\begin{array}{l}143 \% \\
(3 \%)\end{array}$ \\
\hline Debt-capital ratio, $\overline{\widetilde{d}}$ & $25 \%$ \\
\hline Tax rate on capital income, $\tau^{K}$ & $20 \%$ \\
\hline Social Security pay-as-you-go liabilities tax rate, $\tau_{s \geq 0}^{S S, P}$ & $11.5 \%$ \\
\hline Social Security funded portion tax rate, $\tau_{S \geq 0}^{S S, F}$ & $0.5 \%$ \\
\hline Non-Social Security wage tax rate, $\tau^{W}$ & $15 \%$ \\
\hline
\end{tabular}

Implied Endogenous Variables (same in all simulations)

\begin{tabular}{l|c}
\hline Net national saving rate & $4.4 \%$ \\
\hdashline "On Budget" Spending as a fraction of GDP, $G_{0} /\left[A_{0} k_{0}^{\alpha}\right]$ & $15.3 \%$ \\
\hdashline Capital income tax revenue as a fraction of GDP & $4.8 \%$ \\
\hdashline Non-Social Security wage income tax revenue as a fraction of GDP & $10.5 \%$ \\
\hline
\end{tabular}

Exogenous Parameter (only for the benchmark)

\begin{tabular}{l|l}
\hline Correlation between capital income returns and wages & 0.75 \\
\hline
\end{tabular}


Table 2

Investing the Entire Social Security Trust Fund in Equities $(\phi=1)$ at Time 0:

Changes in Macroeconomic Variables and Equivalent Capital Income Tax Rates on the Mean Growth Path ${ }^{1}$

\begin{tabular}{|c|c|c|c|c|c|c|c|c|c|}
\hline \multirow[b]{2}{*}{$\begin{array}{l}\text { Generation } \\
\text { Index }^{2}\end{array}$} & \multicolumn{4}{|c|}{ Percent Changes } & \multicolumn{5}{|c|}{ Levels (in percent) } \\
\hline & $\begin{array}{l}\text { Capital } \\
\text { Stock }\end{array}$ & $\begin{array}{l}\text { Pre-tax } \\
\text { Wages }\end{array}$ & $\begin{array}{l}\text { Post-tax } \\
\text { Wages }^{3}\end{array}$ & $\begin{array}{l}\text { National } \\
\text { Income }\end{array}$ & $\begin{array}{c}\text { Wage Tax } \\
\text { Rates }\end{array}$ & $\begin{array}{l}\text { Risk-Free } \\
\text { Rate } \\
\text { (Annual) }\end{array}$ & $\begin{array}{l}\text { Expected } \\
\text { Return to } \\
\text { Equities } \\
\text { (Annual) }\end{array}$ & $\begin{array}{c}\text { Equity } \\
\text { Premium } \\
\text { (Annual) }^{4}\end{array}$ & $\begin{array}{c}\text { Equivalent } \\
\text { Capital } \\
\text { Income Tax } \\
\text { Rate }^{5}\end{array}$ \\
\hline \multicolumn{10}{|c|}{ Homogenous Agent Model (Section IV) } \\
\hline 0 & 0.0 & 0.0 & 0.1 & 0.0 & 14.9 & 3.0 & 8.4 & 5.4 & 24.19 \\
\hline 1 & 4.2 & 1.2 & 2.3 & 1.2 & 14.3 & 3.5 & 8.4 & 4.9 & 24.23 \\
\hline 2 & 4.4 & 1.3 & 2.8 & 1.2 & 13.9 & 3.2 & 8.4 & 5.2 & 24.23 \\
\hline 3 & 4.4 & 1.3 & 2.9 & 1.2 & 13.8 & 3.2 & 8.4 & 5.2 & 24.23 \\
\hline 4 & 4.4 & 1.3 & 2.9 & 1.2 & 13.8 & 3.2 & 8.4 & 5.2 & 24.23 \\
\hline 5 & 4.4 & 1.3 & 2.9 & 1.2 & 13.8 & 3.2 & 8.4 & 5.2 & 24.23 \\
\hline \multicolumn{10}{|c|}{ Heterogenous Agent Model (Section V) } \\
\hline 0 & 0.0 & 0.0 & 0.3 & 0.0 & 14.8 & 3.0 & 8.3 & 5.3 & 24.01 \\
\hline 1 & 8.6 & 2.5 & 0.9 & 2.4 & 16.1 & 4.4 & 8.3 & 3.9 & 24.11 \\
\hline 2 & 8.7 & 2.5 & 1.3 & 2.4 & 15.9 & 4.3 & 8.3 & 4.0 & 24.12 \\
\hline 3 & 8.7 & 2.5 & 1.4 & 2.4 & 15.8 & 4.3 & 8.3 & 4.0 & 24.12 \\
\hline 4 & 8.6 & 2.5 & 1.5 & 2.4 & 15.7 & 4.2 & 8.3 & 4.1 & 24.12 \\
\hline 5 & 8.6 & 2.5 & 1.5 & 2.4 & 15.7 & 4.2 & 8.3 & 4.1 & 24.12 \\
\hline
\end{tabular}

Notes:

1. I.e., state variables updated between generations are conditional on all shocks (both productivity and depreciation) taking their mean values ex post.

2. Each generation represents 30 years. Generation 0 is the initial young at the time of the policy change. The timing is such that the policy change is announced before generation 0 optimizes. Hence, the equity premium faced by generation- 0 agents immediately changes. Generation (-1) agents represent the elderly at the time of the reform whose saving and portfolio decisions and after-tax asset returns have already been determined by the time of the policy change.

3. I.e., after federal and Social Security taxes (the latter don't change for these simulations).

4. The equity premium equals 5.5 percent (annual) along the constant growth path before the policy change, reflecting a pre-reform expected return to equities of 8.5 percent (annual).

5. This is the capital income tax rate shown in Theorem 1 (homogenous-agent model) and Theorem 2 (heterogenous-agent model), applied at time $t+1$ to generation- $t$ 's second-period capital income, that would exactly replicate investing the Social Security trust fund in equities. The tax rate was 20 percent along the mean growth path prior to the policy reform. 